\title{
EFFECT OF MOTIVATION AND JOB SATISFACTION ON EMPLOYEE PERFORMANCE THROUGH WORKING DISCIPLINE AT PT. BAMBOO TIRTA ENGINEERING
}

Vol: 1, Issue: 1

September/2020

https://ijbssrnet.com/index.php/ijbssr DOI: 10.47742/ijbssr.v1n1p4

Student Master of Management

Universitas Krisnadwipayana

Campus Unkris Jatiwaringin

PO BOX 7774/Jat CM Jakarta 13077

Indonesia

Suharto

Associate Professor

Universitas Krisnadwipayana

Campus Unkris Jatiwaringin

PO BOX 7774/Jat CM Jakarta 13077

Indonesia

Iwan Kurniawan Subagja

Lecturer and Reseacher

Universitas Krisnadwipayana

Campus Unkris Jatiwaringin

PO BOX 7774/Jat CM Jakarta 13077

Indonesia

\begin{tabular}{l}
\hline A R T I C L E I N F O \\
Article history: Article \\
Received \\
Revised \\
Accepted: September, 2020 \\
DOI: $10.47742 /$ ijbssr.v1n1p4
\end{tabular}

\begin{abstract}
A B S T R A C T
This study aims to: 1) To determine and analyze the effect of motivation and job satisfaction on work discipline, 2) To determine and analyze the effect of motivation and job satisfaction on employee performance, 3) To determine and analyze the effect of work discipline on employee performance, 4) To find out and analyze the influence of motivation and job satisfaction on employee performance through work discipline PT. Bambu Tirta Engineering. The research was conducted at PT. Bambu Tirta Engineering with a research sample of 64 respondents. The sampling technique uses saturated samples. Methods of data analysis using descriptive analysis and quantitative analysis with path analysis.

The results showed that: 1) there is an effect of motivation and job satisfaction on work discipline, 2) there is an effect of motivation and job satisfaction on employee performance, 3) there is an effect of work discipline on the performance of employees of PT. Bambu Tirta Engineering and 4) there is no influence between motivation and job satisfaction on employee performance through work discipline PT. Bambu Tirta Engineering. This means that the direct effect is greater than the indirect effect, the work discipline variable cannot mediate between motivation and job satisfaction on employee performance at PT. Bambu Tirta Engineering.
\end{abstract}

Keywords : Motivation, Job Satisfaction, Work Discipline and Employee Performance

\section{Introduction}

Every company must be able to compete with other companies in winning business. To be able to compete with other companies, the company must have quality resources. If the company does not want to compete with other companies, the company will die either slowly or quickly. Quality resources can produce a good performance.

Performance according to Setiawan and Waridin (2006) is the result or performance of employees that are assessed in terms of quality and quantity based on work standards determined by the organization. Good performance is optimal performance, namely performance that is following organizational standards and supports the achievement of organizational goals. A good organization is an organization that seeks to improve the capabilities of its human resources because this is a key factor in improving employee performance.

According to Mangkunegara (2005), performance (work performance) is the quality and quantity of work achieved by an employee in carrying out his duties according to the responsibilities assigned to him. Sulistiyani (2003) states that a person's performance is a combination of abilities, efforts and opportunities that can be assessed from the results of his work.

Gibson (1996) states that 3 factors influence performance. The first factor is individual factors, such as abilities, skills, family background, work experience, social and demographic level of a person. The second is psychological factors, such as perception, role, personality, motivation and job satisfaction. The third factor is organizational factors, such as organizational structure, job design, leadership and reward 
systems. From the statement, Gibson explains that psychological factors of job satisfaction and organizational factors such as motivation will affect performance.

To achieve maximum employee performance or performance. Internal factors that need to be considered in improving performance are individual motivation to work, job satisfaction and work discipline. Generally, individuals work for reasons to earn income, channel their hobbies to a job, fill their time and so on. However, for professional resources, work activities are professional activities to be able to earn sufficient income for themselves and their families. Strong motivation for a workforce or employee will have an impact on achieving a good level of performance.

Someone's satisfaction at work also plays a role in producing high performance. The higher the level of individual satisfaction at work, the greater the individual's performance will be. Another factor that needs to be considered in improving individual performance is work discipline. Discipline plays an important role in the success of one's work. As a company engaged in engineering, PT. Bambu Tirta Engineering must be able to compete with other companies. One of the strengths of the company is the development of its human resources to produce a good performance. To be able to produce a good performance, management must pay attention to motivation, satisfaction and work discipline of employees at the company.

\section{Literature Review}

\section{Motivation}

Motivation is also defined as a power resource that drives and controls human behavior. Motivation is an effort that can encourage someone to take the desired action, while motive is the power of a person to act. The term motivation comes from the Latin word movere which means to move or move. Because a person's behavior tends to be goal-oriented and driven by the desire to achieve certain goals. Motivation is the willingness of individuals to make high efforts to achieve organizational goals (Robbins, 2001). In the context of work, motivation is an important factor in encouraging an employee to work. There are three key elements in motivation, namely effort, organizational goals and needs.

Therefore, it requires the intensity and quality of these efforts as well as focused on organizational goals. The effort is a measure of intensity. If a person is motivated, he will try his best to achieve goals, but not necessarily high efforts will result in high employee performance. Needs are internal conditions that give rise to impulses, where unsatisfied needs will cause tension that stimulates impulses from within the individual. Employees who are motivated are in a tense state and seek to reduce tension by exerting effort. This impulse gives rise to a search-to-find, specific goal. If there is a need fulfillment, there will be a reduction in stress.

Employee motivation is no less important in contributing to the company. Motivation is the willingness to put more effort into achieving organizational goals, which is caused by a willingness to satisfy individual needs (Robbins, 2001). With the right motivation, employees will be motivated to do their best in carrying out their duties because they believe that with the success of the organization in achieving its goals and objectives, the personal interests of the members of the organization will also be included. High motivation will create a commitment to what is their responsibility in completing each job (McNeese-Smith et al, 1993).

\section{Job Satisfaction}

Job satisfaction is a feeling of pleasure or disappointment for someone who arises after comparing his perceptions or impressions of job satisfaction or work results. Meanwhile, Oliver defines satisfaction as the level of a person's feelings after comparing job satisfaction / perceived results with expectations (Handoko, 2003). So, the level of satisfaction is a function of the difference between perceived job satisfaction and expectations. If job satisfaction is below expectations, then employees will be disappointed, if job satisfaction is as expected, employees will be satisfied.

Employee job satisfaction must be created as well as possible so that employee morale, dedication, love and discipline increased. Job satisfaction is a pleasant emotional attitude and loves his job. This attitude is reflected by work morale, discipline, and work performance. Job satisfaction is enjoyed at work, outside work and a combination of inside and outside work (Hasibuan; 2007: 202).

Employee job satisfaction is influenced by the following factors (Hasibuan; 2007: 203):

a. Fair and proper remuneration.

b. The right placement according to the expertise.

c. The weight of work.

d. Work atmosphere and environment.

e. Equipment that supports the implementation of work.

f. The attitude of the leader in his leadership.

$\mathrm{g}$. The nature of work is monotonous or not.

\section{Discipline}

Work discipline is a person's compliance and willingness to obey all company rules and prevailing social norms. This discipline can be carried out using preventive discipline, namely disciplinary action to encourage employees to comply with various applicable regulations and comply with established standards. Discipline is a corrective discipline, which is an action taken after a rule violation occurs. This action is to prevent further violations so that future actions comply with the standard. The type of discipline is self-discipline, namely the learning process from family and society.

Self-discipline is the discipline expected by the organization. If the organization's expectations are met, employees will receive an award from the organization, whether in the form of performance or other compensation. The second discipline is group discipline. Group discipline will be achieved if self-discipline has grown in employees. This means that the group will produce optimal work if each member of the group can contribute according to their rights and responsibilities. 
Group discipline sometimes contributes to the development of self-discipline.

Discipline can be seen from personality factors which consist of obedience, discipline due to identification, discipline due to internalization. Other factors that need to be considered are environmental factors, namely self-discipline, group discipline.

\section{Employee Performance}

The definition of performance according to Siswanto (2005: 235) states that performance is the result of work in quality and quantity achieved by a person in carrying out the tasks and jobs assigned to him. Rivai (2005: 309) states that performance is a real behavior that is displayed by each person as a work achievement produced by employees following their role in the company. the results of work or activities of an employee in quality and quantity in an organization to achieve goals in carrying out the tasks and jobs assigned to him.

Measuring employee performance according to Dharma (2003: 355) which is quoted from saying that almost all ways of measuring performance consider the following:

1. Quantity, namely the amount that must be completed or achieved.

2. Quality, namely the quality that must be produced (whether good or not). The qualitative measurement of
Vol: 1, Issue: 1

September $/ 2020$

https://ijbssrnet.com/index.php/ijbssr

DOI: 10.47742/ijbssr.v1n1p4

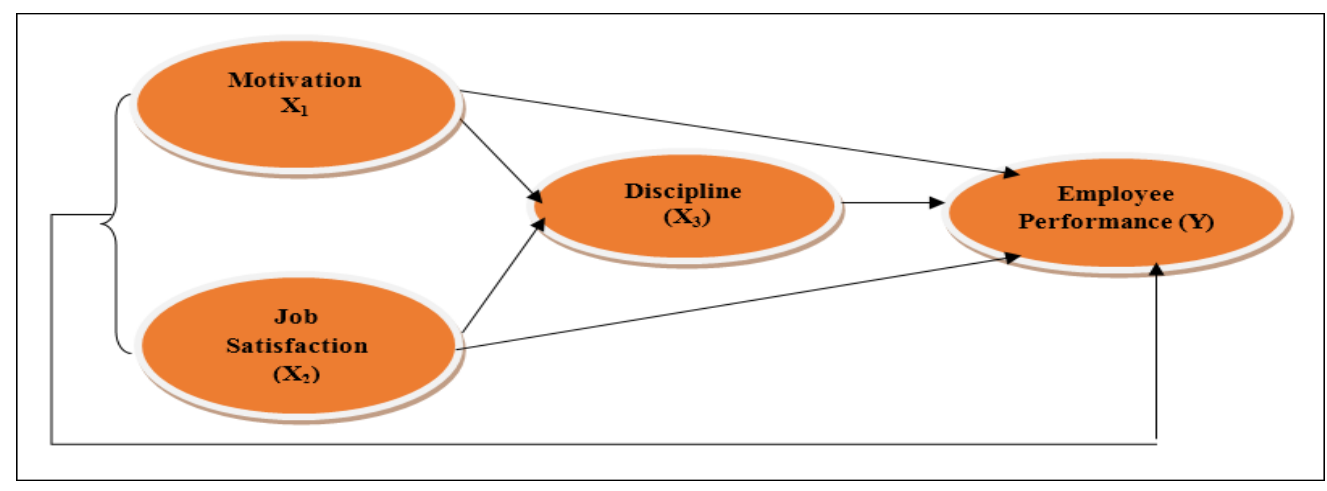

Figure 1. Research Model

\section{Population and Sample}

The population is a generalization area consisting of objects/subjects that have certain quantities and characteristics set by the researcher for the study and then draw conclusions (Sugiyono, 2005). The sample is a part of the population to represent the entire population (Surakhmad, 1990). The sample used by the authors in this study were company employees.

The total number of employees is 64 people. The total number of works is assumed to be entirely in data analysis as the research sample. The sampling technique uses saturated samples. The samples included are company employees who work without paying attention to years of service and education level.

\section{Research Results and Discussion}

1.Analysis of the Effect of Motivation and Job Satisfaction on Work Discipline

According to Ghozali (2006: 211), the path coefficient uses standardized regression coefficients. The results output reflects the measurement or level of satisfaction, namely how well it is completed

3. Punctuality, that is, according to the planned time.

Meanwhile, according to Mathis (2006: 78) which is an indicator in measuring employee performance or achievement are as follows:

1.Work quantity, namely the volume of work produced under normal conditions.

2.Quality of work, which can be in the form of neatness, accuracy and linkage of results without neglecting the volume of work.

3.Time utilization, namely the use of the working period adjusted to the policy of the company or government institution.

4.Cooperation, namely the ability to handle relationships with other people at work

\section{Research Methods}

\section{Research Objects}

Buyung Bay KP No 47 North Bekasi City of Bekasi West

Java.

\section{Research Design}

This study uses an explanatory analysis approach. This means that every variable presented in the hypothesis will be observed through testing the causal relationship of the independent variable to the dependent variable.

of the regression analysis of the influence of motivation and job satisfaction on work discipline show the value of R2 (R Square) of 0.627 . The value of $\mathrm{R} 2$ is used in calculating the value of the el coefficient. The coefficient el is a variant of work discipline that is not explained by motivation and job satisfaction. Magnitude: The coefficient of e1 $=0.610$

Based on the results of data analysis, the regression equation can be seen as follows:

$$
\begin{array}{ll}
X_{3} & =b_{1} X_{1}+b_{2} X_{2}+e_{1} \\
X_{3} & =0,460 X_{1}+0,396 X_{2}+0,610 e_{1}
\end{array}
$$

The equation shows that:

- Every increase of 1 motivation will be followed by an increase in work discipline by 0.460 .

- Every increase of 1 unit of job satisfaction, will be followed by an increase in work discipline by 0.396 . 
So that from equation (1) it can be seen that if motivation then works discipline will increase. Likewise, with increased job obtained as follows: satisfaction, work discipline will increase.
Vol: 1, Issue: 1

September $/ 2020$

https://ijbssrnet.com/index.php/ijbssr

DOI: 10.47742/ijbssr.v1n1p4

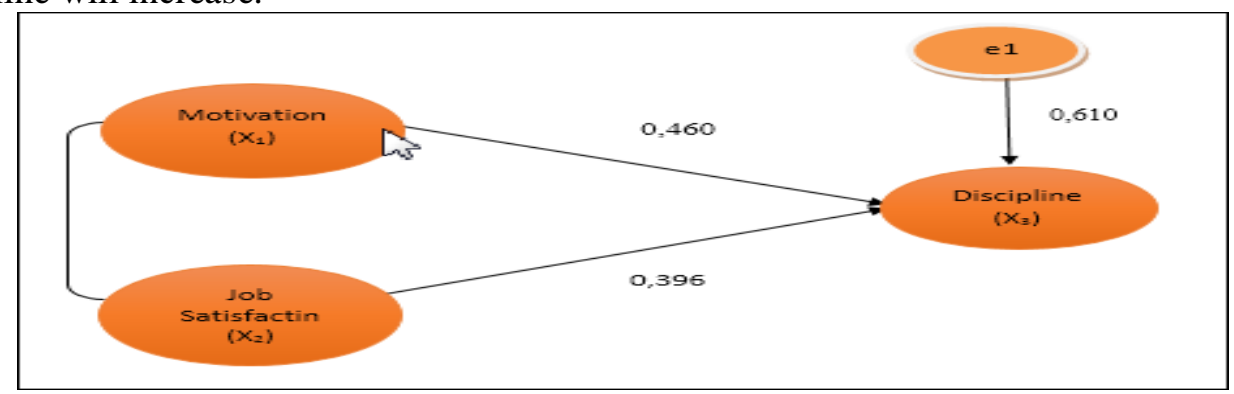

Source: Primary data processed, 2020

Figure 2. Substructure Equations 1

2. Analysis of the Influence of Motivation,

Job Decision and Work Discipline on Employee Performance

The results of regression analysis of the influence of motivation, job satisfaction and work discipline on employee performance can show a value of R2 (R Square) of 0.682. The value of $\mathrm{R} 2$ is used in calculating the value of the e 2 coefficient. The coefficient e2 is a variant of employee performance that is not explained by motivation, job satisfaction, and work discipline. Magnitude: The coefficient of e2 $=0.564$

Based on the results of data analysis, it can be seen that the regression equation is as follows:

$$
\begin{array}{ll}
\mathrm{Y}= & \mathrm{b}_{1} \mathrm{X}_{1}+\mathrm{b}_{2} \mathrm{X}_{2}+\mathrm{b}_{3} \mathrm{X}_{3}+\mathrm{e}_{2} \\
\mathrm{Y}= & 0,238 \mathrm{X}_{1}+0,100 \mathrm{X}_{2}+0,553 \mathrm{X}_{3}+0,564 \mathrm{e}_{2}
\end{array}
$$

The equation shows that:
- Every time there is an increase of 1 unit of motivation, an increase in employee performance will be followed by 0.238 .

- Every time there is an increase of 1 unit of job satisfaction, will be followed by an increase in employee performance by 0.100 .

- Every time there is an increase of 1 unit of work discipline, an increase in employee performance will be followed by 0.553 .

So from equation (2), it can be seen that if the motivation is then employee performance will increase. If job satisfaction increases, employee performance will also increase. Likewise, if work discipline increases, employee performance will also increase

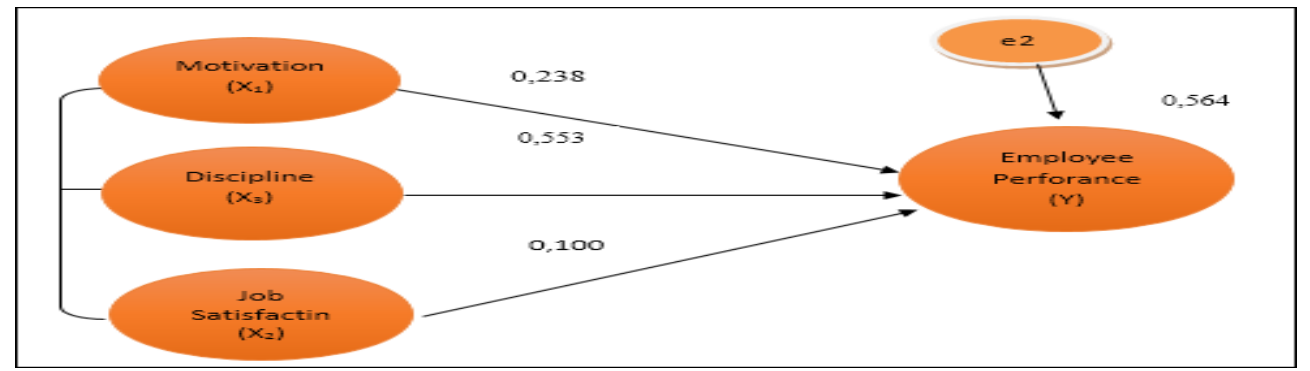

Source: Primary data processed, 2020

Figure 3. Substructure Equations 2

Based on equations (1) and (2), a path analysis model is obtained as follows:

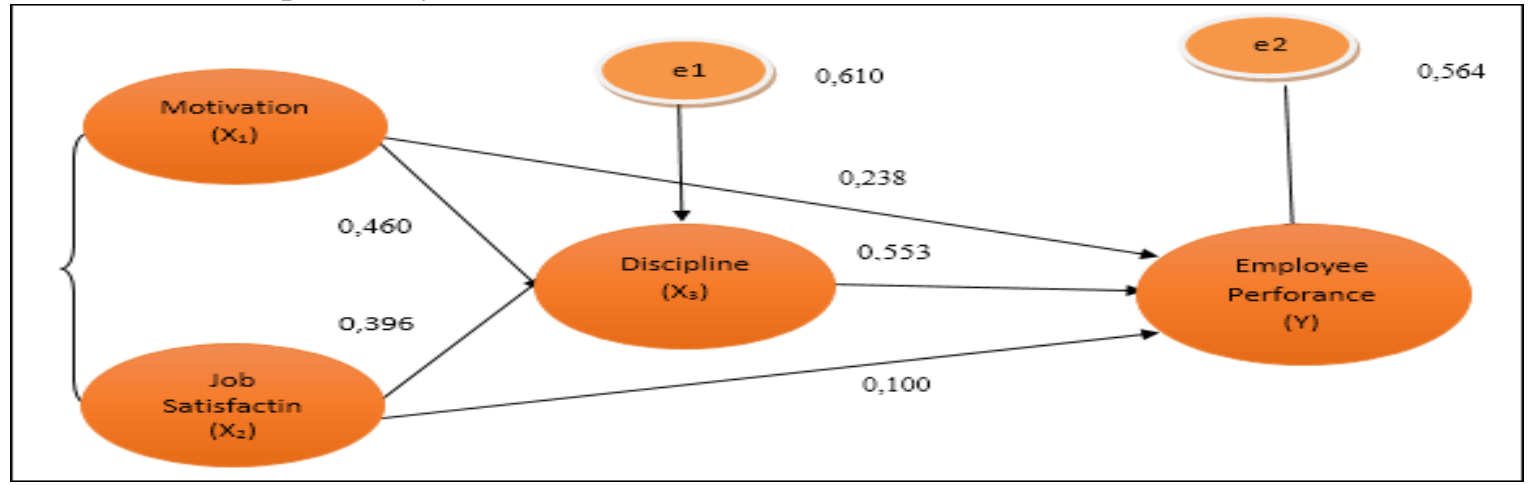

Figure 4. Path Analysis Model 


\begin{abstract}
Hypothesis Test
1. It is suspected that there is an influence of motivation and job satisfaction on work discipline

To find out this, it is necessary to use the t-test. Based on the results of the analysis, it was found that the t-count value of the motivation variable was 4.148 , while the t-table value was 1.663 and the $t$-count value for the job satisfaction variable was 3.575 , while the t-table value was 1.663 . T-count $>t$-table (4.148> $1.663)$ and (3.575> 1.663), thus $\mathrm{H} 0$ is rejected and $\mathrm{H} 1$ is accepted at that real level. This concludes that motivation and job satisfaction affect work discipline. Thus the first hypothesis is tested and proven.
\end{abstract}

2. It is suspected that there is an influence of motivation and job satisfaction on employee performance

To test the effect of motivation and job satisfaction on employee performance, a t-test is used. The results of the t-test for the motivation variable obtained the $\mathrm{t}$-count value $=4.121$, and the t-table value of 1.663 and the job satisfaction variable obtained the $t$-count value $=2.675$, and the t-table value of 1.663 . This means that $t$-count $>\mathrm{t}$-table $(4.121>1.663)$ and $(2,675>$ 1.663), which means that $\mathrm{H} 0$ is rejected and $\mathrm{H} 1$ is accepted. This concludes that motivation and job satisfaction affect employee performance. Thus, the second hypothesis is tested and proven.

3. It is suspected that there is an influence of work discipline on employee performance

To test the effect of work discipline on employee performance, the t-test is carried out. The following are the results of the t-test. The t-test results for the work discipline variable obtained the $\mathrm{t}$ value $=10.572$, and the $\mathrm{t}$-table value of 1.663 . This means that t-count> t-table (10.572> 1.663), which means that $\mathrm{H} 0$ is rejected and $\mathrm{H} 1$ is accepted. This concludes that work discipline affects employee performance. Thus the third hypothesis is tested and proven.

4. It is suspected that there is an influence of motivation and work aging on employee performance through work discipline

$\mathrm{X}_{1} \rightarrow \mathrm{X}_{3} \rightarrow \mathrm{Y}=\left(\rho \mathrm{x}_{3} \mathrm{x}_{1}\right) \mathrm{x}\left(\mathrm{\rho y}_{3}\right)=0,238 \mathrm{x} 0,553=0,132$

$\mathrm{X}_{2} \rightarrow \mathrm{X}_{3} \rightarrow \mathrm{Y}=\left(\mathrm{\rho x}_{3} \mathrm{x}_{2}\right) \mathrm{x}\left(\rho_{\mathrm{y}} \mathrm{x}_{3}\right)=0,100 \mathrm{x} 0,553=0,055$

In the motivation variable, the value of the indirect effect is obtained from the path coefficient value $\rho \times 3 \times 1$ multiplied by the path coefficient value $\rho y x 3$. The multiplication result shows that the value of the indirect effect coefficient is smaller than the value of the direct effect coefficient. In the job satisfaction variable, the indirect effect value is obtained from the path coefficient value $\rho \times 3 \times 2$ multiplied by the path coefficient value pyx3. The multiplication result shows that the value of the indirect effect coefficient is smaller than the value of the direct effect coefficient. This shows that work discipline cannot mediate, namely motivation and job satisfaction in influencing employee performance.

\section{Total Effect}

a. The influence of motivation on employee performance through work discipline
$\mathrm{X}_{1} \rightarrow \mathrm{X}_{3} \rightarrow \mathrm{Y}=\rho \mathrm{yx}_{1}+\left\{\left(\rho \mathrm{x}_{3} \mathrm{x}_{1}\right) \mathrm{x}\left(\rho \mathrm{yx}_{3}\right)\right\}=0,238+0,553$ $=0,791$

The total influence arising from motivation on employee performance through work discipline is equal to 0,791 .

b. The effect of job satisfaction on employee performance through work discipline

$\mathrm{X}_{2} \rightarrow \mathrm{X}_{3} \rightarrow \mathrm{Y}=\rho \mathrm{yx}_{2}+\left\{\left(\rho \mathrm{x}_{3} \mathrm{X}_{2}\right) \mathrm{x}\left(\rho \mathrm{yx}_{3}\right)\right\}=0,100+0,553$ $=0,653$

The total influence arising from job satisfaction on employee performance through work discipline is equal to 0,653 .

c. The influence of motivation on employee performance $\mathrm{X}_{1} \rightarrow \mathrm{Y}=\operatorname{\rho yx}_{1}=0,238$

The total influence arising from motivation on employee performance is equal to 0,238

d. Effect of job satisfaction on employee performance

$\mathrm{X}_{2} \rightarrow \mathrm{Y}=\rho \mathrm{yx}_{2}=0,100$

The total influence arising from job satisfaction on employee performance is equal to 0,100

e. Effect of work discipline on employee performance $\mathrm{X}_{3} \rightarrow \mathrm{Y}=\mathrm{\rho yx}_{3}=0,553$

The total influence arising from work discipline on employee performance is 0.553 .

1. The Effect of Residual Coefficient Variables on work discipline. The coefficient of e $1=0.610$

2. The Effect of Residual Coefficient Variables on employee performance. The coefficient of e $2=0.564$

\section{Discussion}

\section{Discipline \\ 1. Effect of Motivation and Job Satisfaction on Work}

Based on the analysis of the description of the motivation variable, it shows that the best outcome indicators provide the greatest contribution to the formation of the motivation variable, namely that employees can achieve the best results in working at the company because employees think that colleagues are important to ask for help but do not always wait for their colleagues' orders to give the best results. Based on the analysis of job satisfaction variable descriptions, it shows that the dedication to work indicator gives the greatest value to the formation of job satisfaction variables, namely that employees have high dedication in carrying out work so that every job is considered special. Based on the analysis of the description of the work discipline variable, it shows that the indicators of leadership are acting fairly and supervising the largest contribution to the formation of work discipline variables, namely the leader always acts fairly and supervises the work of employees so that high discipline is created. Based on the results of the path analysis, it shows that motivation and job satisfaction has an impact on increasing work discipline. The results of the research are in line with research conducted by Ichlapio Fitrianto, Hasmin, Akmal Umar (2016), Rizki Novriyanti Zahara, Hajan Hidayat (2017), Cedaryana, Muchlis R. Luddin, Yetti Supriyati (2018), Harry Kurniawan, Heryanto (2019), Sebastiao Costa Rangel Sousa 
Simoes, Gde Riana, Made Subudi (2017) and Natalia Susanto, (2019).

\section{Effect of Motivation and Job Satisfaction on Employee Performance}

Based on the results of the descriptive analysis of the employee performance variables, it shows that the initiative indicators make a major contribution to the formation of employee performance variables, namely employees have a high initiative attitude at work. Based on the analysis of the description of the motivation variable, it shows that the best outcome indicators provide the greatest contribution to the formation of the motivation variable, namely that employees can achieve the best results in working at the company because employees think that colleagues are important to ask for help but do not always wait for their colleagues' orders to give the best results. Based on the analysis of job satisfaction variable descriptions, it shows that the dedication to work indicator gives the greatest value to the formation of job satisfaction variables, namely that employees have high dedication in carrying out work so that every job is considered special. Based on the analysis of the description of the work discipline variable, it shows that the indicators of leadership are acting fairly and supervising the largest contribution to the formation of work discipline variables, namely the leader always acts fairly and supervises the work of employees so that high discipline is created. Based on the results of the path analysis, it shows that motivation and job satisfaction has an impact on improving employee performance. The results of the research are in line with the research conducted by Ichlapio Fitrianto, Hasmin, Akmal Umar (2016), Rizki Novriyanti Zahara, Hajan Hidayat (2017), Cedaryana, Muchlis R. Luddin, Yetti Supriyati (2018).

\section{The Effect of Work Discipline on Employee \\ Performance}

Based on the results of the descriptive analysis of the employee performance variables, it shows that the initiative indicators make a major contribution to the formation of employee performance variables, namely employees have a high initiative attitude at work. Based on the analysis of the description of the work discipline variable, it shows that the indicators of leadership are acting fairly and supervising the largest contribution to the formation of work discipline variables, namely that the leader always acts fairly and supervises the work of employees so that high discipline is created.

Based on the results of the path analysis, it shows that work discipline has an impact on improving employee performance. The results of the research are in line with the research conducted by Ichlapio Fitrianto, Hasmin, Akmal Umar (2016), Rizki Novriyanti Zahara, Hajan Hidayat (2017), Cedaryana, Muchlis R. Luddin, Yetti Supriyati (2018).

\section{The Effect of Motivation and Job Satisfaction on} Employee Performance through Work Discipline

Based on the analysis of the description of the motivation variable, it shows that the best outcome indicators provide the greatest contribution to the formation of the motivation variable, namely that employees can achieve the best results in working at the company because employees think that colleagues are important to ask for help but do not always wait for their colleagues' orders to give the best results. Based on the analysis of job satisfaction variable descriptions, it shows that the dedication to work indicator gives the greatest value to the formation of job satisfaction variables, namely that employees have high dedication in carrying out work so that every job is considered special. Based on the analysis of the description of the work discipline variable, it shows that the indicators of leadership are acting fairly and supervising the largest contribution to the formation of work discipline variables, namely the leader always acts fairly and supervises the work of employees so that high discipline is created. Based on the results of the path analysis, it shows that motivation and job satisfaction has an impact on increasing work discipline. Based on the results of the descriptive analysis of the employee performance variables, it shows that the initiative indicators make a major contribution to the formation of employee performance variables, namely employees have a high initiative attitude at work. Based on the analysis of the description of the work discipline variable, it shows that the indicators of leadership are acting fairly and supervising the largest contribution to the formation of work discipline variables, namely the leader always acts fairly and supervises the work of employees so that high discipline is created.

Based on the results of the path analysis shows that motivation and job satisfaction on employee performance through work discipline does not have an impact on improving employee performance. The results of the research are not in line with the research conducted by Ichlapio Fitrianto, Hasmin, Akmal Umar (2016), Rizki Novriyanti Zahara, Hajan Hidayat (2017), Cedaryana, Muchlis R. Luddin, Yetti Supriyati (2018), Ni Nengah Rupadi Kertiriasih, I Wayan Sujana, I Nengah Suardika (2018), Dini Yunita Ayundasari, Achmad Sudiro, Dodi Wirawan Irawanto (2017) and I Ketut R. Sudiarditha, Dewi Susita, Tri Mulyani Kartini (2019).

\section{Conclusions and Recommendations}

\section{Conclusion}

Based on the results of the research analysis and discussion, it can be concluded as follows:

\section{a. Based on the analysis description:}

1) Motivation

Based on the analysis of the description of the motivation variable, it shows that the best outcome indicators provide the greatest contribution to the formation of the motivation variable, namely that employees can achieve the best results in working at the company because employees think that colleagues are important to ask for help but do not always wait for their colleagues' orders to give the best results.

2) Job Satisfaction

Based on the analysis of job satisfaction variable descriptions, it shows that the dedication to work indicator gives the greatest value to the formation of job satisfaction variables, 
namely that employees have high dedication in carrying out 3 . work so that every job is considered special.

3) Work Discipline

Based on the analysis of the description of the work discipline variable, it shows that the indicators of leadership are acting fairly and supervising the largest contribution to the formation of work discipline variables, namely the leader always acts fairly and supervises the work of employees so that high discipline is created.

4) Employee Performance

Based on the results of the descriptive analysis of the employee performance variables, it shows that the initiative indicators make a major contribution to the formation of employee performance variables, namely employees have a high initiative attitude at work.

\section{b. Based on Path Analysis:}

1) Based on the results of the path analysis, it shows that motivation and job satisfaction has an impact on increasing work discipline.

2) Based on the results of the path analysis, it shows that motivation and job satisfaction has an impact on improving employee performance.

3) Based on the results of the path analysis, it shows that work discipline has an impact on improving employee performance.

4) Based on the results of the path analysis, it shows that motivation and job satisfaction on employee performance through work discipline does not have an impact on improving employee performance.

\section{Recommendations}

The research results are expected to be useful both theoretically and practically, namely:

1. For the development of science, it is hoped that this research can be useful for the development of science, especially HR management in the study of factors that affect employee performance.

2. For the author, it is hoped that this research can be a means of developing the skills that the authors acquire in college.
This research is expected to be useful for PT. Bambu Tirta Engineering in increasing sales and company development by considering:

a. The results of this study are expected to be used as a thoughtful contribution to PT. Bambu Tirta Engineering, taking into account the motivational variables, especially for the idea acceptance indicator which gives the lowest score for the motivation variable, is that the company must accept new ideas from employees through informal meetings or meetings and appreciate those ideas from subordinates.

b. The results of this study are expected to be used as a thoughtful contribution to PT. Bambu Tirta Engineering, by paying attention to job satisfaction variables, especially for indicators of expectations for work results that give the lowest value to job satisfaction variables, namely using which employees must have the hope of being able to carry out their work properly following orders obtained by their superiors or the company and the company must provide rewards for employees who give loyalty to the company.

4. The results of this study are expected to be used as a thoughtful contribution to PT. Bambu Tirta Engineering, by paying attention to work discipline variables, especially for leading indicators, provides an example that gives the lowest value for work discipline variables, namely that the leader must provide a good example to employees in carrying out daily tasks so that it will lead to employee discipline.

The results of this study are expected to be used as a contribution of thought for PT. Bambu Tirta Engineering, by paying attention to employee performance variables, especially for work quality indicators that give the lowest value to employee performance variables, namely by the way the leadership must pay attention to and evaluate the work results of employees who have good quality following company expectations and employees who have good personal qualities in work to support good work results by providing bonuses or incentives and for employees who are not performing well are given sanctions so that it can be corrected.

\section{References}

Agus, Dharma. (2003). Manajemen Supervisi: Petunjuk Praktis Bagi Para Supervisor. Edis i Revisi. Cetakan kelima. Jakarta: RajaGrafindo Persada.

Allen, NJ., Meyer PJ. And Smith CA. (1993). "Commitment to Organizations and Occupations: Extension and Test of a ThreeComponent Conceptualization”, Journal of Applied Psychology, Vol. 78, No. 4.

Ambar Teguh Sulistiyani dan Rosidah, (2003), Manajemen Sumber Daya Manusia, Graha Ilmu, Yogyakarta.

Basri, A. F. M., dan Rivai, V. (2005). Performance Appraisal. Jakarta: PT Raja. Grafindo Persada.

Budi, Setiyawan dan Waridin. (2006). Pengaruh Disiplin Kerja Karyawan dan Budaya Organisasi Terhadap Kinerja di Divisi Radiologi RSUP Dokter Kariadi, Semarang: JRBI. Vol 2. No 2. Hal: 181-198

Cedaryana, Muchlis R. Luddin, Yetti Supriyati (2018). Influence of Work Discipline, Career Development and Job Satisfaction on Employee Performance Directorate General Research and Development of Ministry Research, Technology and Higher Education. International Journal of Scientific Research and Management (IJSRM). Volume 06, Issue 02, Pages EL-201887-96. 
Dini Yunita Ayundasari, Achmad Sudiro, Dodi Wirawan Irawanto (2017). Improving Employee Performance Through Work Motivation And Self-Efficacy Mediated By Job Satisfaction, Journal of Applied Management (JAM), Volume 15 Number 4, December 2017.

Gibson, James L. et al. (1996). Organisasi: Perilaku, Struktur, Proses. Diterjemahkan oleh Ninuk Adriani. Jakarta: Binarupa Aksara. Handoko, T. Hani Handoko . (2003) . Manajemen . Edisi 2 . Penerbit BPFE Yogyakarta, Yogyakarta.

Harry Kurniawan, Heryanto (2019). Effect of Work Discipline and work Environment on Employee Performance with Work Motivation as an Intervening Variable in the Department of Tourism, Youth and Sport of Padang District. Archives of Business Research, Vol.7, No.7.

Hasibuan, Malayu S.P (2007), Manajemen Sumber Daya Manusia Perusahaan, Bandung, PT. Bumi Aksa.

I Ketut R. Sudiarditha, Dewi Susita, Tri Mulyani Kartini (2019). Compensation And Work Discipline On Employee Performance With Job Satisfaction As Intervening. Trikonomika, Volume 18, No. 2, December 2019, Page. 80-87.

Ichlapio Fitrianto, Hasmin, Akmal Umar (2016). Pengaruh Motivasi, Disiplin, Dan Kepuasa Kerja, Terhadap Kinerja Karyawan PT. Bumi Rama Nusantara, Jurnal Mirai Management, Volume 1 Nomor 1, April-September 2016

Mangkunegara, Anwar Prabu. 2005. Evaluasi Kinerja SDM, Cetakan Kedua Bandung: Rafika Aditama.

Mathis, Robert L, dan John Jackson, (2006), Manajemen Sumber Daya Manusia, Jakarta : PT. Salemba Empat.

Natalia Susanto, (2019). Pengaruh Motivasi Kerja, Kepuasan Kerja, Dan Disiplin Kerja Terhadap Kinerja Karyawan Pada Divisi Penjualan Pt Rembaka. Agora Vol. 7, No. 12019

Ni Nengah Rupadi Kertiriasih, I Wayan Sujana, I Nengah Suardika. (2018). The Effect of Leadership Style to Job Satisfaction, Employee Engagement and Employee Performance (Study at PT. Interbat, Bali, Nusra, and Ambon). International Journal of Contemporary Research and Review. Vol. 9, Issue. 03, Page no: ME 20592-20600.

Rahmat Setiawan, Bustari Muchtar, Abror (2018). The Effects of Leadership Function, Work Motivation and Job Satisfaction on Employee's Work Discipline at STIKes Fort De Kock Bukittinggi. Advances in Economics, Business and Management Research, volume 64.

Rizki Novriyanti Zahara, Hajan Hidayat (2017). Pengaruh Kepuasan Dan Disiplin Kerja Terhadap Kinerja Karyawan Bank Di Kota Batam. Journal of Applied Managerial Accounting. Vol. 1, No. 2, 2017, 150-156.

Robbins, Stephen P. (2001). Perilaku Organisasi: Konsep, Kontroversi, Aplikasi, Jilid 1, Edisi 8, Prenhallindo, Jakarta.

Sebastiao Costa Rangel Sousa Simoes, Gde Riana, Made Subudi (2017). Pengaruh Motivasi Kerja Dan Disiplin Diri Terhadap Kepuasan Dan Kinerja Karyawan Kantor Kabupaten Ainaro Timor Leste. E-Jurnal Ekonomi dan Bisnis Universitas Udayana 6.10 (2017): 3463-3476.

Siswanto, (2005), Pengantar Manajemen, Jakarta, Bumi Aksara.

Sugiyono. (2005). Memahami Penelitian Kualitatif. Bandung: CV. Alfabeta.

Winarno Surakhmad, (1990), Pengantar Penelitian Ilmiah, Tarsito, Bandung 